\title{
In Vitro Propagation of Chrysanthemum: an Overview on its Utility in Mutagenesis and Genetic Transformation Techniques
}

\author{
Fardin Nasri ${ }^{1 *}$, Hedayat Zakizadeh ${ }^{1 *}$, Yavar Vafaee ${ }^{2}$, Ali Akbar Mozafari ${ }^{2}$ \\ ${ }^{1}$ Department of Horticultural Sciences, University of Guilan, Iran \\ ${ }^{2}$ Department of Horticultural Science, University of Kurdistan, Iran
}

Submission: March 29, 2018; Published: April 25, 2018

"Corresponding author: Fardin Nasri, Department of Horticultural Sciences, Faculty of Agricultural Sciences, University of Guilan, Rasht, Iran, Email: Zakizadeh55@yahoo.com

Hedayat Zakizadeh, Department of Horticultural Sciences, Faculty of Agricultural Sciences, University of Guilan, Rasht, Iran,

Email: Fardin.Nasri1@.gmailcom

Abstract

Chrysanthemum morifolium within Asteracea family which is one of the most important cut flower and pot species. Callus tissue is genetically unstable and regeneration via this tissue is associated with the occurrence of somaclonal variation or chimera structure. The use of ray florets and leafy tissues for the in vitro propagation of C. morifolium for shoot regeneration (Direct and indirect) or somatic embryogenesis is of great importance for the mutagenic breeding programs and genetic transformtion of this species. Cytokinin and auxin hormones have been effective in shoot regeneration and creating calluses in C. morifolium species. The ability to regenerate shoots from callus is essential for establishing a successful plant culture system as well as in vitro mutagenesis. In this mini review, induction of embryogenic callus and direct organogenesis and importance of these methods in mutagenesis and genetic transformation are described.

Keywords: Tissue culture; Embryogenic callus; Organogenesis; Mutation; Somaclonal variation

Abbreviations: PGRs: Plant Growth Regulators; BAP: N6-benzylaminopurine; NAA: a-Naphthalene Acetic Acid; IBA Indole-3-Butryic Acid; IAA: Indole Acetic Acid; 2,4-D: 2,4 Dichloro Phenoxy Acetic Acid; MS: Murashige and Skoog (1962) Medium

\section{Introduction}

Chrysanthemum morifoliumspecies belong to the Asteraceae family and is one of the most important cut flower and pot species on the market that traditionally propagated by root suckers or terminal cuttings [1]. These methods are very slow processes, and the risk of transmission of the virus and other diseases is very high [2]. Tissue culture techniques can improve the efficiency of plant propagation processes and as well as facilitates the rapid replication and development of superior genotypes [3]. There are numerous reports on the in vitro regeneration of chrysanthemum, which chiefly have been regenerated through the passage of the callus phase [4-6].

Previous studies have examined the impact of various Chrysanthemum explant types such as leaf [7], pedicle [8], protoplast [9], shoot bud [10] and stem [11] on callus induction and organogenesis. The regeneration of shoots by organogenesis is one of the main methods in vitro propagation of chrysanthemum and many other plant species $[7,9,11]$. Efficient direct organogenesis of Chrysanthemum using leaf explants was achieved using a higher concentration of cytokinin than of auxin $[12,13]$. It seemed that the endogenous level of cytokines contained in leaves of Chrysanthemum is too low to induce shoot regeneration. De Jong J et al. [14] reported regeneration of adventitious shoots from leaves of in vitro grown chrysanthemum (Dendranthema grandiflora Tzvel.) without passing through the callus phase.

Production of regenerated plant through indirect organogenesis is one possible method to help to Chrysanthemum genetically modified (Figure 1). Furthermore, callus production is also a useful tool in genetic improvement of Chrysanthemum species in order to introduce useful genes or producing new cultivars $[6,15]$.

Regeneration efficiency in chrysanthemum is reacted by the PGRs interaction, plant genotype and types of explant $[16,17]$. Diversity in adventitious shoot regeneration of various cultivars 
has been reported in chrysanthemum cultivars [4-5,9,18,19]. Song JY, et al. [5] reported significant differences in perentage of regeneration among various cultivars when grown on media supplemented with different concentrations of auxin and cytokinin. Likewise, a cytokinin and auxin combination has been reported to be important for efficient shoot organogenesis for chrysanthemum $[10,20,21]$.

In most studies, direct shoot formation were observed in MS medium supplemented with high concentrations of cytokinin and lower of auxin. Direct organogenesis requires the reinitiation of cell division by the use of PGRS [22]. Waseem K, et al. [23] reported that the lower concentration of auxin is apt for shoot regeneration in chrysanthemum. Against, concentrations of higher could easily produce calli but shoots formation is very poor. Based on previous studies, increasing the concentration of BAP from 2 to $4 \mathrm{mg}$ L-1resulted in a decrease in the average number of shoots and the mean shoot length. This disincentive eeffect has been attributed to a Embryogenic undesirable influence of BAP on protein synthesis [24].

\section{Callus induction}

In previous studies, the explants were unable to produce callus on MS medium without growth regulators. Callus induction was observed only when the MS medium containing auxin compounds (2,4-D, NAA, IBA and IAA) was prepared alone in combination with cytokinin $[1,2,5,15,16,25]$. Therefore, adding the auxin compounds to the medium is essential for callus induction [26,27]. Both cytokinin and auxin have been effective in creating calluses in chrysanthemum species (Figure 1). The rate of callus production increased with increasing concentration 2,4-D (2-4mg L-1) and then decreased with higher concentrations. With further increase in the concentration of 2,4-D, the callus turned brownish. Thomas \& Maseena [28]

\section{Regeneration of embryogenic callus}

reported that, a range of 2,4-D concentrations (0.1-2.0mg L-1) is necessary for embryogenic callus formation from leaf and nodal explants. Obukosia SD, et al. [29] reported that the MS medium containing $2 \mathrm{mg} \mathrm{L}-1 \mathrm{~L}$ 2,4-D was a favorable media for induction of callus in Chrysanthemum plants.

Overall, it can be suggested that before using tissue culture techniques as tools in crop improvement, it is essential to determine the factors influencing callus induction, its quality during formation and retain and then shoot regeneration from callus.

\section{Induction of somatic embryos}

Developing somatic embryogenic culture systems with reliable regeneration capacity from ornamental plants is a prerequisite for mass propagation and their genetic improvement. The process can be induced in tissue cultures of chrysanthemum either directly from the epidermal cells of explants [26] or indirectly via intervening callus [30,31]. Somatic embryogenesis was observed by adding BAP in the presence of 2,4-D (Figure 1). In addition, the ratios between 2,4-D and BAP concentrations were significantly associated with the percentages of somatic embryogenesis and number of somatic embryos. Shinoyama $\mathrm{H}$, et al. [30] reported combination of $2 \mathrm{mg} \mathrm{L}-12,4-\mathrm{D}$ and $2 \mathrm{mg}$.L-1 kinitin was found to be as optimal concentration for somatic embryos induction. Also, Tymoszuk A, et al. [32], using ray florets, concluded that $85 \%$ of the explants were able to produce embryos, and in each ray florets about 5.70 somatic embryos were placed on the MS medium containing $4 \mathrm{mg} \mathrm{L-1}$ of 2,4-D and $1 \mathrm{mg}$ L-1of kinetin. Indirect somatic embryogenesis has been reported in many other chrysanthemus genotypes [25,26,30,31]. With regard to the previous results, the use of embryogenesis in mutagenic breeding programs could be very useful

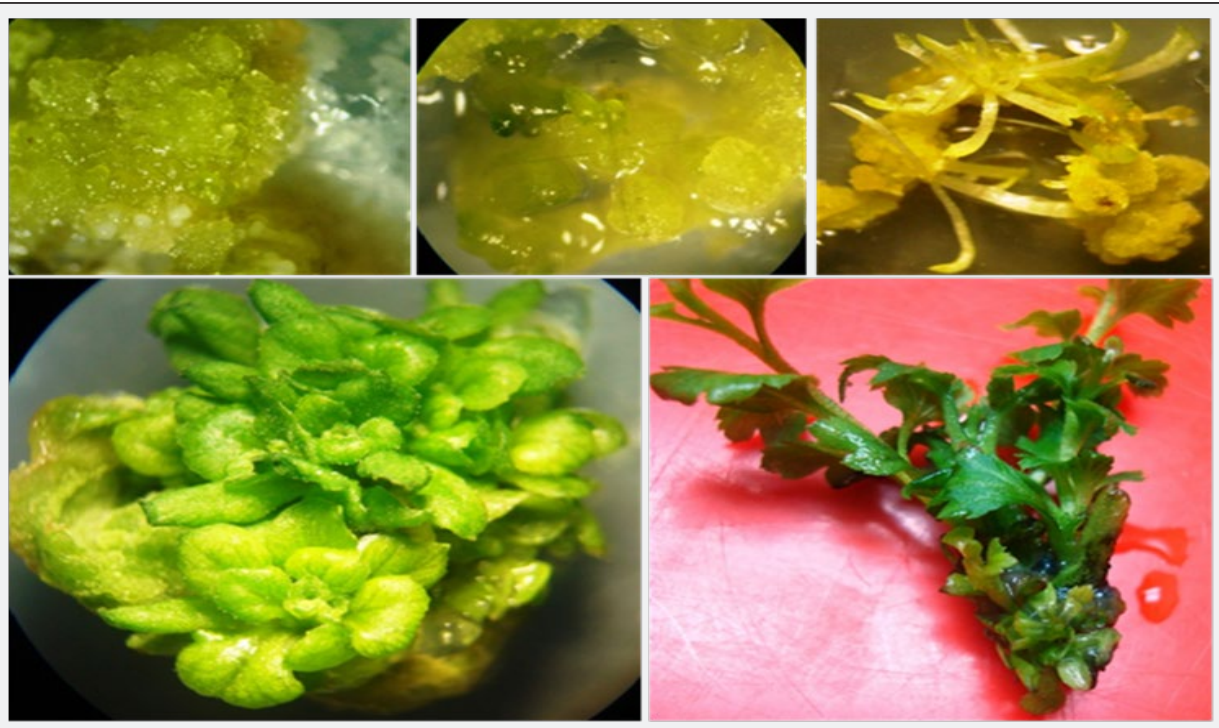

Figure 1: Different stages of callus induction, somatic embryos and plant regeneration and direct organogenesis in Chrysanthemum morifolium. A: Embryogenic sections of callus; B: Embryos in different stages; C and D: shoot-primordia and shoots multiplication from callus; E: Direct organogenesis from shoot tip. 
The ability to regenerate shoots from callus is essential for establishing a successful plant culture system as well as in vitro mutagenesis (Figure 1) .The findings show that induction of embryogenesis and plant regeneration are significantly related to genotypes [5,33]. Cytokinin plays an important role in the regeneration of shoot from callus in vitro conditions [34]. Auxins and cytokinins are an important factor in the induction of embryogenesis due to inclusive and effective interventions in cell cycle and cell division [35].

\section{Importance of tissue culture in the production of new cultivars}

Tissue culture is an essential tool for creating new chrysanthemum cultivars [1]. The most common type of chrysanthemum breeding is mutation breeding. Mutagenesis has had a positive influence in chrysanthemum biotechnology [36-38], leading to the production of novel flower colours, modified architecture and leaf chimeras, some of which have been stably propagated. Callus tissue is genetically unstable and regeneration via this tissue is associated with the occurrence of somaclonal variation. Ray florets explants are a useful source for the formation of adventitious shoots or somatic embryogenesis in creating novel cultivars of chrysanthemum [1,2,39]. In addition, leaf explants may be a useful source of new variation in the plant, which may be due to the somaclonal variation or chimera structure in regenerated plants [40].

\section{Conclusion}

Auxin/cytokinin balance is required to obtain adventitious shoot induction as well in embryogenic callus induction and plant regeneration.Optimization of in vitro propagation of Chrysanthemum morifolium by direct organogenesis and embryogenic callus induction can be used for genetic transformation and for further in vitro mutagenesis investigations.

\section{References}

1. Teixeira da Silva JA (2014) Organogenesis from chrysanthemum Dendranthema x grandiflora (Ramat.) Kitamura petals (disc and ray florets) induced by plant growth regulators. Asia-Pacific Journal of Molecular Biology and Biotechnology 22 (1): 145-151

2. Silva JA, Shinoyama H, Aida R, Matsushita Y, Raj SK, et al. (2013) Chrysanthemum biotechnology: Quo vadis? Critical Reviews in Plant Sciences 32(1): 21-52.

3. Shahzad A, Parveen S, Sharma S, Shaheen A, Saeed T et al. (2017) Plant Tissue Culture: Applications in Plant Improvement and Conservation. In: Plant Biotechnology: Principles and Applications, Springer, Singapore, pp. 37-72.

4. Teixeira da Silva JA (2004) Ornamental chrysanthemums: improvement by biotechnology. Plant Cell Tissue and Organ Culture 79: 1-18.

5. Song JY, Mattson NS, Jeong BR (2011) Efficiency of shoot regeneration from leaf, stem, petiole and petal explants of six cultivars of Chrysanthemum morifolium. Plant Cell Tissue Organ Culture 107: 295304.

6. Miler N, Zalewska M (2014) Somaclonal variation of chrysanthemum propagated in vitro from different explants types. Acta Scientiarum Polonorum Horticulture13(2): 69-82.
7. Himstedt JP, Jacobsen HJ, Fisher-Kluver G (2001) Shoot regeneration from stem and leaf explants of chrysanthemum (Dendranthema $x$ grandiflorum). Acta Horticulturae 560: 421-424.

8. Petty LM, Harberd NP, Carre' IA, Thomas B, Jackson SD, et al. (2003) Expression of the Arabidopsis Gai gene under its own promoter causes a reduction in plant height in Chrysanthemum by attenuation of the gibberellin response. Plant Sciences 164: 175-182.

9. Sauvadet MA, Brochard P,Gibod JB (1990) A protoplast to plant system in chrysanthemum: differential responses among several commercial clones. Plant Cell Reports 8: 692-695.

10. Waseem K, Jilani MS, Khan MS (2009) Rapid plant regeneration of chrysanthemum (Chrysanthemum morifolium L.) through shoot tip culture. African Journal of Biotechnology 8: 1871-1877.

11. Jevremovic' S, Radojevic LJ (2004) Mass production of different chrysanthemum (Chrysanthemum morifolium) cultivars by culture in vitro. Journal of Science and Agricultural Research 65: 47-54.

12. Gao Y, Bo Z, Guoxun D, Qixiang Z (2001) Shoot regeneration from stem and leaf explants of Dendrathemagrandiflorum. Journal of Beijing Forestry University 23(1): 32-33.

13. Kim MJ, Kim YH (1988) Plant regeneration and flavonoid 3',5'hydroxylase gene transformation of Dendranthema zawadskii and Dendranthema indicum. Journal of the Korean Society for Horticultural Science 39 (3): 355-359.

14. De Jong J, Rademaker W, Vanwordragen MF (1993) Restoring adventitious shoot formation on chrysanthemum leaf explants following cocultivation with agrobacterium tumefaciens. Plant Cell Tissue Organ Culture 32: 263-270.

15. Kengkarj P, Smitamana P, Fujime Y (2008) Assessment of Somaclonal Variation in Chrysanthemum (Dendranthema grandiflora Kitam.) using RAPD and Morphological Analysis. Plant Tissue Culture and Biotechnology, 18(2): 139-149.

16. Nahid JS, Shyamali S, Kazumi H (2007) High frequency shoot regeneration from petal explants of Chrysanthemummorifolium Ramat In vitro. Pak J Biol Sci 10: 3356-3361.

17. Barakat MN, Abdel Fattah Rania S, Badr M;El-Torky,MG (2010) In vitro culture and plant regeneration derived from ray florets of Chrysanthemum morifolium. African Journal of Biotechnology 9: 11511158.

18. Annadana S, Rademaker W, Ramanna M, Udayakumar M, De Jong J (2000).Response of stem explants to screening and explant source as a basis for methodical advancing of regeneration protocols for chrysanthemum. Plant Cell Tissue \& Organ Culture 62(1):47-55.

19. Lim K.B, Kwon SJ, Lee SI, Hwang J, Naing (2012) Influence of genotype, explant source, and gelling agent on in vitro shoot regeneration of chrysanthemum. Horticulture Environment and Biotechnology 53, 329-335.

20. Jeong JH, Chakrabarty D, Kim SJ, Paek KY (2002) Transformation of chrysanthemum (Dendranthemagrandiflorum)Kitamura cv. Cheonsu by constitutive expression of rice OsMADS1 gene. Journal of the Korean Society for Horticultural Science 43, 382-386.

21. Karim MZ, Amin MN, Azad MAK, Begum F, Islam MM, et al. (2003) Effect of different plant growth regulators on in-vitro shoot multiplication of Chrysanthemum morifolium. On Line Journal of Biological Sciences 3(6): 553-560.

22. Benson EE (2000) In vitro plant recalcitrance: an introduction. In vitro Cellular and Develomental Biology-Plant 36: 141-148.

23. Waseem K, Khan MQ, Jaskani J, Khan MS (2008) Impact of different auxins on the regeneration of Chrysanthemum (Dendranthema morifolium) through in-vitro shoot tip culture. Pakistan Journal of Agricultural Research 20 (1-2): 51-57. 
24. Staden J, Crounch N (1996) Benzyladenine and derivatestheir significance and interconversion in plants. Plant Growth Regulation 19: 153-175.

25. Naing AH, Kim CK, Yun BJ, Jin JY, Lim KB (2013) Primary and secondary somatic embryogenesis in Chrysanthemum cv. Euro. Plant Cell Tissue Organ Culture 112: 361-368.

26. Mandal AKA, Datta SK (2005) Direct somatic embryogenesis and plant regeneration from ray florets of chrysanthemum. Biologia Plantarum 49(1): 29-33.

27. Barakat MN (2008) Application of In vitro Culture for Resistance to Desertification. Meterology, Enviroment and Arid Land Agriculture 19:

3-18.

28. Thomas TD, Maseena EA (2006) Callus induction and plant regeneration in Cardiospermum halicacabum (L.) an important medicinal plant. Scientia Horticulturae 108L: 332-336.

29. Obukosia SD, Kimani E, Wathaika K, Mutitu E, Kimani PM (2004) Effect of growth regulators and genotypes on pyrethrum in vitro. In vitro Cellular and Develomental Biology-Plant 11: 162-166.

30. Shinoyama H, Nomura Y, Tsuchiya T, Kazuma T (2004) A simpleand efficient method for somatic embryogenesis and plant regeneration from leaves of Chrysanthemum (Dendranthema grandiflora (Ramat.) Kitamura). Plant Biotechnology 21: 25-30.

31. Tanaka K, Kanno Y, Kudo, S, Suzuki M (2000) somatic embryogenesis and plant regeneration in Chrysanthemum (Dendranthema grandiflora (Ramat.) Kitamura). Plant Cell Reports 19: 946-953.

32. Tymoszuk A, Zalewska M, Lema-Rumin'ska J (2014) Regeneration of somatic embryos from in vitro isolated ligulate florets of chrysanthemum. Acta Sci Pol Hortorum Cultus 13(4):13-22.
33. Zhao C H, Zhang L J, Ge C, Hu K (2008) Establishment and optimization of the regeneration system of mature embryos of maize (Zea mays L.). Agricultural Sciences in China 7: 1046-1051.

34. Xu, Um, Kim HC, LuG, Guo DP, et al. (2008) Effect of plant growth regulators, temperature and sucrose on shoot proliferation from the stem disc of Chinese jiaotou (Allium chinense) and in vitro bulblet formation. Acta Physiology Plant 40: 521-528.

35. Francis D, Sorrell DA (2001) The interface between the cell cycle and plant growth regulators: a mini review. Plant Growth Regulation 33: $1-12$.

36. Datta SK, Teixeira da Silva JA (2006) Role of induced mutagenesis for development of new flower colour and type in ornamentals. In: Teixeira da Silva JA (Ed.), Floriculture, ornamental and plant biotechnology: advances and topical issues 1470, (1 ${ }^{\text {st }}$ edn), Global Science Books Ltd. Isleworth, pp. 640-645.

37. Okamura M, Tanaka A, Momose M, Umemoto N, Teixeira da Silva JA, et al. (2006) Advances of mutagenesis in flowers and their industrialization. In: Teixeira da Silva JA (Ed.), Ornamental and plant biotechnology: advances and topical issues. ( $1^{\text {st }}$ edn), Global Science Books Ltd, Isleworth, pp. 619-628.

38. Kong Y, Bai JR, Shang HZ, Wang NY (2013) Application of heavy ion beam irradiation in ornamental flowers breeding. Acta Horticulturae Sinica 40(9): 1837-1845.

39. Teixeira da Silva JA, Dobra'nszki J (2015) Problems with traditional science publishing and finding a wider niche for post-publication peer review. Accountability Res: Policies Qual Assur 22(1): 22-40.

40. Zalewska M, Lema-Rumińska J, Miler N (2007) In vitro propagation using adventitious buds technique as a source of new variability in chrysanthemum. Scientia Horticulturae 113(1): 70-73.

\begin{tabular}{|l|}
\hline \multicolumn{1}{|c|}{ Your next submission with Juniper Publishers } \\
will reach you the below assets \\
- Quality Editorial service \\
- Swift Peer Review \\
- Reprints availability \\
- E-prints Service \\
- Manuscript Podcast for convenient understanding \\
- Global attainment for your research \\
- Manuscript accessibility in different formats \\
( Pdf, E-pub, Full Text, Audio) \\
- Unceasing customer service \\
Track the below URL for one-step submission \\
https://juniperpublishers.com/online-submission.php \\
\hline
\end{tabular}

